
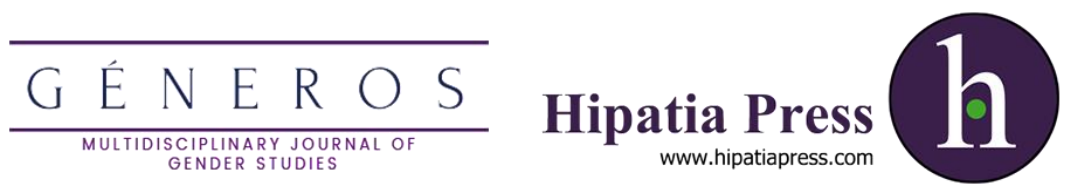

Instructions for authors, subscriptions and further details:

\title{
http://generos.hipatiapress.com
}

\section{Rainwater Harvesting as a Strategy for Adapting to Climate Change and Building Women's Autonomy in Brazilian Semiarid Regions}

Daniela Nogueira ${ }^{1}$

Patricia Mesquita ${ }^{1}$

Louise Cavalcante ${ }^{2}$

Saulo Rodrigues Filho ${ }^{1}$

Carlos Saito ${ }^{1}$

1) University of Brasilia

2) Wageningen University and Research

Date of publication: February 25th, 2022

Edition period: February - June 2022

To cite this article: Nogueira, D., Mesquita, P., Cavalcante, L., RodriguesFilho, S. \& Saito, C. (2021). Rainwater Harvesting as a Strategy for Adapting to Climate Change and Building Women's Autonomy in Brazilian Semiarid Regions. Multidisciplinary Journal of Gender Studies, 11(1), 72-97. doi: $10.17583 /$ generos.6673

To link this article: https://doi.org/10.17583/generos.6673

PLEASE SCROLL DOWN FOR ARTICLE

The terms and conditions of use are related to the Open Journal System and to Creative Commons Attribution License (CC-BY). 
GÉNEROS -Multidisciplinary Journal of Gender Studies Vol. 11 No.1 February 2022 pp. 72-97

\title{
Rainwater Harvesting as a Strategy for Adapting to Climate Change and Building Women's Autonomy in Brazilian Semiarid Regions
}

\author{
Daniela Nogueira \\ Patricia Mesquita \\ Saulo Rodrigues Filho \\ Carlos Saito \\ University of Brasilia
}

Louise Cavalcante

Wageningen University and Research

\begin{abstract}
The Cisterns Program aims to mitigate drought impacts by strengthening the adaptive capacity of vulnerable inhabitants in Brazilian semiarid (BSA) regions. Cisterns promote farmers' ability to adapt to climatic stresses in the long run. This article discusses the impacts of the Rainwater Harvesting Program (RHP) on the livelihoods of women in BSA regions. The policy implementation is assessed in terms of capacity building, social mobilization, and the construction of infrastructure that guarantees rainwater harvesting for human consumption and productive uses. Based on semistructured interviews in case studies in Paraíba, Pernambuco and Ceará States, this article discusses how the gender perspective can improve adaptive capacity. The results from the case studies indicate important changes in female autonomy and increased independence related to water access, resulting in extra time for women to dedicate to other activities, including education. Moreover, the availability of water for production strengthened productive capacity, leading to greater food security and well-being. Last, a sense of economic independence related to income generation from improved production capacity was also reported.
\end{abstract}

Keywords: wáter security, gender, adaptation

2022 Hipatia Press

ISSN: 2014-3613

doi: $10.17583 /$ generos. 6673

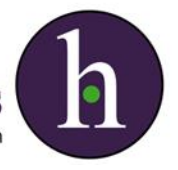




\title{
La Captación de Agua de Lluvia como estrategia de Adaptación al Cambio Climático y Construcción de la Autonomía de las Mujeres en el Semiárido Brasileño
}

\author{
Daniela Nogueira \\ Patricia Mesquita \\ Saulo Rodrigues Filho \\ Carlos Saito \\ University of Brasilia
}

Louise Cavalcante

Wageningen University and Research

\section{Resumen}

El Programa Cisternas tiene como objetivo mitigar impactos de la sequía mediante la capacidad de adaptación de los habitantes del semiárido brasileño (BSA). Este artículo analiza los impactos del Programa en los medios de vida de las mujeres. La implementación de políticas ha sido evaluada desde el desarrollo de capacidades y movilización social hasta la construcción de infraestrutura de captación de agua de lluvia para consume humano y usos productivos. Basado en entrevistas semiestructuradas aplicadas a estudios de caso en los estados de Paraíba, Pernambuco y Ceará, este artículo discute cómo la perspectiva de género promove impactos socioeconómicos y mejora la capacidad de adaptación. Los resultados de los estudios de caso indicaron cambios importantes en la autonomía femenina, promovidos por una mayor independencia relacionada con el acceso al agua, lo que resultó en tiempo adicional para otras actividades, incluida la educación. Además, la disponibilidad de agua para la producción ha fortalecido la capacidad productiva y ha conducido a una mayor seguridad alimentar y bienestar. Por último, también se informó sobre una sensación de independencia económica relacionada con la generación de ingresos a partir de la mejora de la capacidad de producción.

Palabras clave: seguridad del agua, género, adaptación 
ater insecurity imposes several limitations on productive activities and livelihoods in rural areas. In Brazilian semiarid (BSA) regions, the low rainfall pattern, along with great spatial and temporal variability and high evaporation rates, has historically caused several periods of prolonged drought. These droughts have been responsible for crop failure and social impacts reported since colonial times (Lemos, 2007; Marengo, 2008; Hastenrath, 2011).

The conventional approach to combating drought has led to several failures. According to Lindoso et al. (2018), the causes are related to "the concentration of water resources, land concentration, and the government' $\mathrm{s}$ top-down approaches, following a developmentalism logic and often importing alien models being ill-adapted to the BSA regions' environmental and culture particularities". Therefore, over time, this conventional governance paradigm changed to the coexistence paradigm, which includes a systemic vision of the environment, with geophysical, social, economic, political and cultural dimensions (Silva, 2003). In this context, water access technologies, more specifically cisterns, began to play an important role in Brazilian semiarid regions. The new paradigm of "coexistence with the semiarid" appeared more recently, in the 1990s, with strategies for coexisting with the conditions of the semiarid region and for mitigating or/and adapting to the effects of drought. This concept brought the recognition of social participation and the empowerment, culture, and practices of local communities to any strategy or public policy implemented in this area.

\section{Different paths leading to the universalization of water access}

During the Conference of the Parties to the UN Convention to Combat Desertification (COP-3, 1999), the Articulation of the Semiarid (ASA) launched a declaration on the possibility of living with drought in the semiarid. The Declaration of the Semiarid (ASA, 1999) presented a central message in favor of the feasibility of adaptation measures to cope with the region's physiographic conditions (Silva, 2014). The declaration started with two key premises. The first is the need for the conservation, sustainable use and recomposition of semiarid natural resources, and the second is the need 


\section{Nogueira, Mesquita, Cavalcante, Rodrigues, Saito- Rainwater Harvesting}

for an end to the monopoly of access to land, water and other means of production. It was in this context that the discussion and initiatives related to the later "Cisterns Program" began.

This program started from locally conceived actions, and given its promising results, it became a government program over the years. This path was based on several arrangements, first initiated through a pilot project agreement for the construction of cisterns for human consumption $\left(1^{\text {st }}\right.$ Water or Consumption Cisterns) agreed upon between the ASA and the Ministry of the Environment in 2000 (Ferreira, 2009; Costa \& Dias, 2013).

In 2003, the project became a public policy of the federal government (currently referred to as the National Support Program for Rainwater Harvesting and other Social Technologies - Cisterns Program), with a specific budget within the Zero Hunger Program, with impacts not only in the semiarid region but also in other Brazilian regions (Lima et al., 2007; Nogueira, 2017). At that time, the One Million Rural Cisterns Program (P1MC) coordinated by the ASA was able to expand and diversify the use of social technologies aimed at human consumption. In 2007, the ASA initiated the One Land and Two Waters Program (Programa Uma Terra e Duas Águas or P1+2), launching the construction of water technologies for production $\left(2^{\text {nd }}\right.$ Water or Production Cisterns) for beneficiaries of the original technology.

In 2011, under the "Brazil Without Extreme Poverty Plan" (Brasil Sem Miséria-BSM), the federal government began to promote universal water access in rural areas as a fundamental component to overcome extreme poverty, especially in Brazilian semiarid regions (Campos et al., 2014). With the setting of more ambitious targets for installing $1^{\text {st }}$ and $2^{\text {nd }}$ water technologies, the water access component was included in the program called Water for All (Água para todos) under the dimension of productive inclusion.

The programs targeted families living in rural areas of municipalities in the Brazilian semiarid region, with no source of drinking water near their homes or with precarious existing sources. Selection for inclusion was based on the following additional criteria: 1) families headed by women; 2) families with children aged 0 to 6 years; 3) families with children and/or adolescents attending school; 4) families with adults aged 65 or over; and 5) families with physically and/or mentally disabled members. Thus, the gender perspective appeared to be one of the pillars in the program implementation (both in the 
strategies mediated by ASA and in the strategies of partnership with the state and consortium of municipalities via the federal government). As a consequence, the gender perspective was mainstreamed in the design of methodologies to be used during implementation (Bennett, V. et al, 2008).

From this perspective, Bisilliat \& Verschuur (2000) stated that the insertion of gender mainstreaming in the formulation and implementation of more inclusive policies is a relevant driver for development. It is a political strategy that simultaneously articulates the reduction of vulnerability and promotes sustainable development. For example, regarding access to the $1^{\text {st }}$ water program ( $1^{\text {st }}$ Water), several impacts have been observed, such as greater female autonomy and general improvement in citizenship, with increased free time for engaging in social and health activities (Nogueira, 2009). These impacts are related to the direct relationship between the availability of water and the gender division of domestic work (Kergoat, 2000; Hirata, 1998).

Nevertheless, Jackson (1998), although recognizing divisions of labor as a central concept in gender-water debates (Bennett, V. et al., 2008), recommended careful analysis to avoid an overemphasis on the separation of genders, rather than integration and interdependence in men-women relations and excessive reliance on physical resource availability. In BSA regions, droughts increase the burden of women's work and add the need for displacement to greater distances for accessing water, which frequently lacks quality and reasonable conditions of potability, resulting in an increased number of waterborne diseases among children and other family members (Nogueira, 2009; Grant, 2017; Sena et al, 2018).

Thus, it is necessary to review the linkage between water access and gender equality, and in this context, climate change and social technologies should be added into the analysis. In this region, more frequent and longer periods of water scarcity are predicted (PBMC, 2013), and social technologies play an important role in adaptation, in response to not only regular periods of drought but also long-lasting droughts resulting from climate change.

Based on the articulation between water security, climate change, and gender, this article analyzes the local perception of impacts generated by rainwater harvesting technologies. In particular, it explores how cisterns for domestic consumption and production affect women's daily lives and 


\section{Nogueira, Mesquita, Cavalcante, Rodrigues, Saito- Rainwater Harvesting}

discusses how these technologies can contribute to the process of adaptation to climate change in BSA regions. Additionally, it discusses to what extent water access can enhance the adaptive capacity of women by generating conditions for enhancing their autonomy.

The study is based on primary and secondary data, including bibliographic data and program evaluation studies, institutional documents, and interviews conducted in two field campaigns (2007/2008 and 2018). ${ }^{1}$ The methodological framework aims to foster results regarding the perceptions of impacts from the beneficiaries and institutional actors involved in the program and, finally, to analyze the relationship between water, gender, and climate change, as well as the importance of cisterns as an adaptation strategy for the region.

\section{Methodology}

The analysis represents a combination of data collected in two different periods and research projects: a) the first one during 2007-2008 and b) the second one in 2018. Altogether, Brazilian semiarid rural communities were investigated in Pernambuco (rural communities near Jupi and São Bento do Una), Paraíba (rural communities near Lagoa Seca and Massaranduba) and Ceará States (municipalities of Itapipoca, Santa Quitéria, Itatira, and Quixeramobim).

In the first stage, 27 semistructured interviews were conducted with women who benefited from the consumption cisterns, 15 of them also included their families. In addition to these women (and families), 10 institutional actors (state and national-level policy-makers) external to the program and 13 internal actors were interviewed. The interview script consisted of eight guiding questions organized according to thematic blocks related to the participants' socioeconomic profile; the form of access to water, the time spent fetching water before and after the cistern was constructed, and 
the impact on their livelihoods. Several other methodological practices were integrated, including the observation of women through the collection of discursive data gathered in different spaces of socialization and the elucidation of the meaning of water and the place occupied by this 'resource' in their daily life.

In the second stage, interviews related to the production cisterns were conducted in 2018, when the research team visited a BSA area in the state of Ceará (October), and later that year (November) with institutional actors related to the program (federal district). At this time, 16 households with production cisterns were visited in the municipalities of Itapipoca, Santa Quitéria, Itatira and Quixeramobim (Ceará). Interviews were conducted with women, men, and when possible, with couples. In addition, there were interviews with 5 federal public managers who worked with this public policy, 2 state coordinators and 3 field technicians responsible for implementing the program. The interviews consisted of open-ended questions on the status of family agriculture in the region, the production cistern implementation process, and the interviewees' perception of the impacts. In both stages of this research, the questionnaire was presented to the interviewees, who subsequently provided formal authorization to use the information.

\section{Results - Perception of Impacts}

\section{Consumption Cisterns - Pernambuco and Paraíba State}

According to the perceptions of the interviewed women $\left(\mathrm{N}^{1}=27\right), 100 \%$ reported an improvement in their daily life (Table 1). The women stated that the access to water brought an improvement in health (49.7\%); the possibility of having a productive area close to home (field or backyard) and the potential generation of an extra income (18.6\%); and time saved without the requirement of long daily walks $(53.1 \%)$. 


\section{Nogueira, Mesquita, Cavalcante, Rodrigues, Saito- Rainwater Harvesting}

Table 1

Improvement in Women's Daily Lives

\begin{tabular}{cc}
\hline $\begin{array}{c}\text { Type of } \\
\text { Improvement }\end{array}$ & Percentage (\%) \\
\hline Health & 49.7 \\
Extra Income & 18.6 \\
Saved Time & 53.1 \\
\hline Total (N=27) & 100 \\
\hline
\end{tabular}

Source: elaborated by the authors based on field research.

The "saved time" emerged from the beneficiaries' narratives as a common positive impact, independent of autobiographical aspects, such as age, marital status, family structure, income, race or religion. The saved time appeared recurrently in interviews with women, given the role of this group in domestic water management, as represented by the statement of one interviewee: "at that time, early in the morning, you were already thinking about water, now is a rest". Thus, time was an important asset that was used as a guiding thread, influencing lives before and after the cistern but also in new temporalities, since in theory, the economizing of time created space for other activities. Consequently, it was necessary to analyze how "time" was related to the other listed impacts.

As referred to in Table 1, the benefits listed - "health", "income" and "time" - were linked to the existence of cisterns and consequently of water. However, the framework of their relationships allowed us to distinguish between direct and indirect benefits. The direct benefits were those that, as the name implies, were linked directly to the presence of cisterns: health, time and income. The 
indirect benefits were the developments reported as a result of saved time, in this case, income and health.

While time appeared simultaneously as a direct benefit and an indirect benefit influencing other developments, health and income emerged as fluctuating categories, which sometimes appeared as direct benefits and at other times as time-mediated benefits. Health, which in the broad sense includes water, food and nutritional security, appeared as a direct benefit to the whole family when it emerged as a result of access to better water quality and as a "source of health for the family". Activities related to the maintenance of cisterns and water treatment are taught to those responsible for the families during the training courses on Water Resources Management, Citizenship and Coexistence with the Semiarid (GRH), included in the program. Participation in the courses is a requirement for the families receiving the cisterns, since the absence or deficiency in water treatment and the ingestion of water not appropriate for human consumption can result in various health problems, such as diarrhea, worm infestation, skin mycosis, and dehydration. On the other hand, still related to the direct impact of cisterns on women's health, a perverse effect was observed in that despite all the benefits brought by the cistern, several interviewees complained about the weight gain resulting from the reduction of long walks in search of water.

Health also emerged as an indirect benefit, as it appeared as a result of the saved time used for the development of activities, with results that led to improvements in food conditions. This improvement was reported through the substitution of industrialized foods for organic foods, as well as the cultivation of vegetables and medicinal plants that favored the traditional knowledge of the communities and offered a possible healthier and more accessible alternative for health treatments.

Concerning income, this appeared as a direct benefit when it emerged as a source of direct or indirect income provided by the possibility of creating or cultivating products that could be traded, even if the opportunity was not channeled into productive activities or exchanged. Income also appeared as a benefit from the economizing generated by the substitution of purchased products with produced products, or even in the economies generated by the lack of need to buy water. Income was also an indirect benefit when inserted into the economizing of time, resulting in the generation of income through 


\section{Nogueira, Mesquita, Cavalcante, Rodrigues, Saito- Rainwater Harvesting}

the establishment of some type of business or even a new job, such as the production of homemade sweets, the creation of a cooperative of lacemakers/farmers or work as a cistern builder.

After analyzing the various relationships that link the cisterns with the benefits perceived by women, it was possible to affirm that the domestication of water flow by rain storage (i.e., having water available at the home) had the greatest impact on the transformation of social temporalities (i.e., productive time versus available daily time). This was also related to income appearing simultaneously as a direct benefit and an indirect benefit leading to other developments, recognized as one of the greatest benefits brought by the program. This was more directly associated with the daily life of women given the configuration of the gender division of labor in semiarid rural areas.

\section{Production Cisterns - Ceará}

Concerning the production cisterns, $81 \%$ of households interviewed (including women, men, and couples) reported that there was an improvement in the "role of women" in the household/production $(\mathrm{N}=16)$. This term was used in the interviews to facilitate the respondents' understanding of issues related to the gender dimension.

Further perceived impacts refer to improvements concerning women's activity in backyard cultivation, greater participation in production and sales, less dependence on money, greater confidence regarding access to water, less time spent collecting water, new learning about food processing for sale, and extra activity (in the sense of distraction and relaxation in watering and planting in the backyard - as "a therapy").

Below are some excerpts from the beneficiaries' interviews:

- "Before there was a small production... Today it's more me planting in the backyard... Before it wasn't like this";

- "I felt happier...[I felt] more valued because I had something of my own" (she sells seedlings and vegetables in the rainy season)";

- "I feel safe... Because then I am confident that the water will be enough...";

- "[I] sought water further away for everything ... Now there is water at home"; 
- "I used to fight more with him [husband - because I stayed more at home]. Now we plant. We've already planted carrots, beets, which we love. Before [the drought] I used to go there to water them...";

- "After it arrived, I had a chance, there were courses... There was a workshop about cooking local candy, beekeeping, etc. And then the market came..." (the wife makes bread, honey bread, and fruit pulp, and the husband sells the products at fairs or delivers to customers);

- "Before I only stayed at home and only harvested green herbs for cooking. [now] I'm always in the middle [of the backyard production]"; - "[My wife] works more in the backyard and takes care of her motherin-law... she participates in the Friday night market... We take turns now".

From the perspective of local technicians involved with the implementation of the production technologies, it was reported that in addition to the patrimonial gain, which could be limited, there was a very important time gain for women, which was more observable from the start of the $1^{\text {st }}$ water cistern and improved with the range of social programs farmers participated in later: "It is the extra time. My mother used to take water and carry it on her head, and now she has the cistern [with more time for other things]; "Sometimes the house is quite simple, but the person lives well. [but] It's not just the cistern... there are other [programs]".

Concerning the inclusion of women and young people more specifically in the various stages of the program, only one institution reported having something for women. In this case, it was indicated that while the idea was to include the whole family, women were more frequently present, especially if the theme was production cisterns of the type "calçadão" (large sidewalk) or "enxurrada" (runoff), while "barreiros" (similar to a clay pit with water) were more specific to the male gender: "If I speak of a sidewalk cistern, I am indicating space for the woman... if I speak of a clay pit, for the man".

Other interviewees indicated that since most of the family leaders in the CadÚnico $^{2}$ were women, they were generally selected. However, one respondent observed that in one of the initial meetings at a community, there was a farmer who declared that he wanted a cistern only if it was in his name and not in his wife's ("I am in charge here"). Initially, the family was left out, but as an exception, the technicians decided to put the technology in his name. Another interviewee reported that the program "has to make it mandatory that 


\section{Nogueira, Mesquita, Cavalcante, Rodrigues, Saito- Rainwater Harvesting}

women go to the SISMA ${ }^{3}$ and other training... they are in the backyard and can more easily go to the exchange in other places with already implemented cisterns..." Furthermore, women could be later responsible for disseminating the knowledge. Additionally, the beneficiary-technician relationship is worthy of attention, since during part of the evaluation of beneficiary families by one of the technicians, it was reported that "women feel more comfortable being interviewed (in the diagnosis) by other women". One of the technicians reported that in a new format of the program (Cisterns with Fomento, a program for extra income for productive activities and technical assistance in the pilot test stage), institutions were requested to focus more on the female population.

In interviews with federal-level managers involved in the production cisterns, it was reported that women's protagonism stood out as strategic for water management, biodiversity, and coexistence in the semiarid region. The $2^{\text {nd }}$ Water cisterns empowered women by reducing the pressure on them concerning domestic activities, engaging them in an activity with the process of participation and knowledge construction, and giving them access to information. The presence at the fair, selling their production, was also important for women because it placed them in a prominent place for their work. On the other hand, the interviewee also reported a concern that water management is additional work for women farmers, as they accumulate another task in addition to domestic work that is not equally distributed.

Another interviewee emphasized that women have a fundamental role in the implementation process since they are present in large numbers in the program (women represent $90 \%$ of the concerned public) and have more attention and greater participation. According to the interviewee, in the past, women were the main group of focus regarding the topic of water because they are responsible for searching for water in multiple sources, until the arrival of the consumption cisterns and their positive impacts. Thanks to the production cisterns, most families currently have women in the family unit responsible for the backyard production of country hens, eggs, vegetable gardens or even goats. Finally, another interviewee pointed out that the role of women is highlighted through increased income and social inclusion. 


\section{Discussion}

\section{Perception of the Cistern Impacts}

Several perceptions of positive impacts were observed during the study. Concerning consumption water, the observations highlighted health impacts, time savings, and garden production close to the house, which, although reported, is not configured as one of the objectives of the $1^{\text {st }}$ Water program (designed exclusively to provide access to water for domestic consumption, associated with drinking, cooking and personal hygiene). In the interviews on the production cistern $\left(2^{\text {nd }}\right.$ Water $)$, the same benefits were listed along with greater access to income and participation in production, less dependence on partners, and greater confidence in having access to water during droughts. Here, it is observed that the perceived impacts are coherent with the program's logical model, with the time variable being of importance in both analyses, and coherent with the gender perspective.

From the interviews conducted with families and especially with women, it was possible to observe a symbolic cut between past and present, marked by access to water and consequently by the existence of cisterns, as illustrated by the interviewees: "this one was born with a cistern" ( $1^{\text {st }}$ Water), and "[I] sought [in the past] water further away for everything... Now there is water at home" ( $2^{\text {nd }}$ Water). It was in this sense that the metaphors used to characterize the time lived before and after cisterns revealed traces of a continuity of relief generated by the presence of water in the vicinity of the home. However, it was also possible to recognize elements of discontinuity of this new relief due to the insufficiency/nonexistence of water to fill the reservoir. Nevertheless, continuity was identified as a predominant link, since even if access to cistern water was interrupted, it could be resumed with water delivered by water tank trucks from the most diverse origins.

The quantitative increase in the number of hours 'available to women' (saved time) was identified as not necessarily being a qualitative change in the use of time by the beneficiaries of $1^{\text {st }}$ Water. The time to obtain water goes far beyond the specific activity of fetching it and involves a set of tasks. These range from organizing utensils that serve as containers (may include requesting utensils/tools on loan from neighbors as well as filling them), which sometimes lasts a few hours, and returning home with the containers of 


\section{Nogueira, Mesquita, Cavalcante, Rodrigues, Saito- Rainwater Harvesting}

water. As noted by Murillo (2006), in the book "El Mito de la Vida Privada: de la entrega al tiempo próprio", the first mandate in the construction of the feminine gender resides in the articulation between learning to be a woman and learning to care for others. This integrity between belonging to the domestic space and the construction of the female gender results in the expropriation of time and the right of women to belong to the public space on equal terms (Fraser, 1992). Technicians involved with the implementation of $2^{\text {nd }}$ Water also reported that women experienced a greater availability of time, which can be contrasted by statements indicating an increase in activities, although this is expressed as a positive change (ex: previously, women were only at home, and currently, they are in the middle of production; after taking courses, women also went to the market fairs; currently, women plant more in the backyard). On the other hand, one of the federal managers reported a concern that women's water management is additional work for women farmers, who are generally responsible for all domestic work.

This discussion may help clarify an apparent contradiction found in the implementation of both programs and consequently during the research. The methodological design of the program ( $1^{\text {st }}$ and $2^{\text {nd }}$ Water $)$ highlights that receiving the technology supports the empowerment of women, as it gives priority to families headed by women to receive cisterns (since they represent the main group registered in CadÚnico). Additionally, the process requires the participation of the household head during training courses and meetings and presumes an increase in women's participation in different spaces of the local public sphere (Fraser, 1992; Habermas, 1989). The discussion about water, from its various meanings, facilitates the articulation between the private domain and the public domain, removing women from a situation of social invisibility by facilitating their insertion in the public sphere through participation in public spaces associated with decision-making related to water management (Nogueira, 2009; Murillo, 2006; Ryan, 1992; Habermas, 1989).

However, according to the first fieldwork ( $1^{\text {st }}$ Water), it was possible to observe a strong presence of women during meetings of all communities, especially during the meetings regarding community participation in the program. However, the possible relationship between women's greater interest in access to water and their participation was not confirmed in the study. The 
existence of disagreements between groups of informants and even among informants of the same group regarding the nature of women's participation should be emphasized. Here, it was observed that men attended more training meetings, which could have compromised the maintenance of cisterns and the water quality since the information was transmitted to men even though women were primarily responsible for household water management. The $2^{\text {nd }}$ Water survey also reported the frequent participation of other family members in training courses, and one of the technicians even suggested that the presence of women enrolled on these occasions should be mandatory, since they were the ones in the productive backyard and would be "more easily able to go to the exchanges" since men would remain to care for the farm and pasture. However, such an obligation could add to the burden of feminine tasks and should therefore be further investigated before any change in programs is made.

This difficulty in translating the gender division of labor from the domestic to the public sphere (Habermas, 1989) has its foundation in the very configuration of the public space as a masculine space, constructed by a concept of labor identity that has as a reference the male worker (Fraser, 1992). Thus, the analysis of the transformation of social temporalities and their relationship with the construction of a greater autonomy of women regarding their own time use is not as natural as it may seem, since it goes through the denaturalization of the domestic as a feminine space and requires a complex differentiation between domestic time and private time (Murillo, 2006; Fraser, 1992).

Domestic time is the time dedicated to activities that include the care of the family and the house, and for women, it is characterized by the performance of activities whose nature supports the mobilization and organization of tasks aimed at the reproduction of daily life and the care of others. On the other hand, private time is characterized by a more creative character and self-care. Thus, the domestic and private time of men and women results from the configuration of different economies of time, which in turn are reproduced in the public sphere through the perpetuation and accentuation of gender inequalities. Numerous studies show that an individual's presence in public spaces is directly proportional to the private time available (Dúran, 2007). Such considerations involve methodological 


\section{Nogueira, Mesquita, Cavalcante, Rodrigues, Saito- Rainwater Harvesting}

difficulties, such as the ways of accounting for domestic time based on the current value models. However, they are fundamental when considering the obstacles of a cultural nature that reproduce centralizing and hierarchical structures instead of reinforcing the tendency for cooperation and partnership. Therefore, in the formulation of public policies aimed at the inclusion and empowerment of women as a necessary condition for development processes, all these aspects must be considered (Fraser, 1992).

\section{Importance of Cisterns for adaptation}

Concerning the influence of the $1^{\text {st }}$ and $2^{\text {nd }}$ Water cisterns in rural households, several points of impact that may be important for increasing adaptive capacity in response to climate change can be observed. These impacts include the existence of reservoirs for the accumulation of rainwater or other sources, increased access to water for domestic consumption and production, greater proximity to water sources and less time spent on collection, access to water with greater potability for domestic consumption, disease prevention, greater productive potential, increased income, participation in new sales spaces, greater autonomy of women, more access to theoretical and practical knowledge, changes in production, and learning (by training), among other impacts observed in our research and the related literature (Gonçalvez, 2013; Silva et al, 2013; Petersen et al, 2014; Pantaleao, 2015; Santos, 2017).

Specifically, related to the productive character, studies have observed several adjustments in production that strengthen the adaptive capacity of producers, which involve, among others, changes in the systems of crop cultivation, nurseries, and soil and water management. Water management can be better adapted through modifications, such as mechanisms for precipitation collection, highly effective irrigation systems, water stock and reuse, and the protection of water sources (Deressa et al., 2009; Yu et al., 2012).

Other water management practices include irrigation during the dormant season, drip irrigation, and changes in the irrigation season (Smit, Skinner, 2002). Regarding crops, there may be adjustments via crop diversification and substitution (genetic varieties and species), the use of salt-tolerant species, and 
agroecological techniques that increase local biodiversity and improve resilience to climate impacts, such as the use of manure and less use of inorganic inputs (Smit, Skinner, 2002; Grainger-Jones, 2012). Concerning animals, more appropriate management through better structures, pasture rotation, diversification of animals, stock control and changes in the pasture season are some of the available options (Smit, Skinner, 2002; Sivakumar, Das, Brunini, 2005; Nhemachena, Hassan, 2007). During periods of drought, households can use the sale of animals as an income generation strategy and thus maintain food security (Ericksen et al., 2010). Other suggested modifications for the development of adaptive capacity in these regions are related to rural technical and extension services, the development of community seed banks, improvements in institutional capacity, knowledge of gender-differentiated vulnerabilities, knowledge exchange, and the construction of weather-resistant storage units (Grainger-Jones, 2012). During the interviews with the technicians and beneficiaries of $2^{\text {nd }}$ Water, it was reported that the program's training considers several of the subjects mentioned herein, indicating that, by increasing knowledge (including agroecological knowledge) and using techniques appropriate to coexistence within the semiarid region, the program could contribute to increasing the adaptive capacity of the beneficiaries. Regarding the contribution of cisterns to increasing women's adaptive capacity, as mentioned above, the cisterns caused a major change, since they are infrastructures that reduce the daily work related to water collection and even in the driest periods, they can be supplied by water-tank trucks. In the absence of cisterns, women's workload, which in normal periods is greater (when paid and unpaid work is considered) than men's workload, increases during periods of drought, when the time spent by men on agricultural production activities decreases (UNSRID, 2016). However, as this fact does not generate compensation in domestic relations, the number of hours women devote to fetching the water needed for minimum household consumption increases, since the amount of water needed also increases during this period, as does the distance to the nearest sources. Another aspect of this dimension is the increased demand for care by the family, since the number of sick people increases during droughts (UNSRID, 2016; Nogueira, 2009). Therefore, the use of rainwater considered in the strategies, along with supporting the aim for coexistence within the semiarid 


\section{Nogueira, Mesquita, Cavalcante, Rodrigues, Saito- Rainwater Harvesting}

regions, is an important resource that can not only support water security and the human right to water but also contribute to a better gender balance in terms of the workload.

Securing the right to water is based on sustainable access to water in terms of quantity, quality and regularity to meet basic needs, thus ensuring minimum conditions for supplying the population (Kahinda, Taigbenu, Boroto, 2010). Nevertheless, regarding the impact on daily life, the issue of access to education was recurrent in the discourse of the participating families. With water closer to home, women and children could attend school regularly, and mothers could follow their children's studies more closely. The historical situation of greater asymmetry regarding the gender division of domestic work caused by the difficult access to water directly affected the well-being of women and girls, confirming previous evaluations that, in this region, the need to seek water meant that many girls could not attend school (Nogueira, 2009). In addition, access to water of quality leads to improvements in the family's health condition, particularly for children, and reduces social and economic vulnerabilities that weaken the adaptive capacity of producers (by the use of financial resources for medicines and the weakening of the production workforce, among others).

Another dimension that should be highlighted is the transformations in the social condition of women during the program implementation. By privileging families headed by women (Suárez, Teixeira, 2012), the program reaffirmed the importance of women's work and knowledge concerning water management, removing them from the social invisibility in which they found themselves. The possibility for these women to maintain a small herd or production due to their access to water (more strongly stimulated as an objective of $2^{\text {nd }}$ Water cisterns) allowed them to participate in a new cycle of integration into the formal economy and social life, reducing poverty rates and, consequently, gender inequalities. In addition, these activities allowed women to participate in the family income generation and thus changed the power relations in the domestic space, since they were perceived by their partners and other family members in another material and symbolic logic, that is, as productive and capable (Nogueira, 2009).

Other gender dimensions directly associated with vulnerability in periods of drought and adaptive capacity to climate change are food and water 
security, which translate into the number, quality, and regularity of meals as well as the quantity/quality of water available for human consumption, animal nutrition, and small crops. As in this culture it is common for women to skip meals to ensure food for their children, the unavailability of water and food makes women more susceptible to malnutrition problems in adulthood. The cisterns, by providing better access to water and increasing productive potential, theoretically minimized such situations and enabled women to experience better health. The overall number of diseases often increases with water shortages, as do problems during pregnancy and postpartum and infant mortality rates (Grigoletto et al., 2014); these problems can also be minimized with the help of these social technologies (together with all other public policies, especially the Family Allowance/Bolsa Família, which provides a conditional monthly money transfer to poor and extremely poor families).

Finally, the attempt to include beneficiaries of the $2^{\text {nd }}$ Water cisterns in other government programs (Milhorance, Sabourin, Chechi, 2018), including credit programs, influenced the different patterns of access to financial sources observed between genders, especially in periods of drought when access to financial sources may be more restricted (UNSRID, 2016; Nogueira, 2009).

\section{Final Considerations}

An analysis of the impacts of the consumption and production cisterns in the process of building women's autonomy can be better performed by analyzing the articulation between the private and public spheres and the combination of autonomy-generating and empowerment actions. Generally, it can be stated that the 'gendered methodological design' in the program is built on the domestic level and includes the cooperation of the whole family (husbands, daughters, and sons), and to these actions are added more sophisticated strategies in which political organization and production go hand in hand, enhancing the program's public dimension. The predominance of actions of this nature is fundamental to better understand the overall impact of cisterns on the lives of these women.

The most concrete impact of the cisterns is the construction of social technology and, consequently, the main changes - more time, better health 


\section{Nogueira, Mesquita, Cavalcante, Rodrigues, Saito- Rainwater Harvesting}

and higher income - that accompany access to water close to home and all the benefits that come with it. However, the presence of cisterns should be analyzed from the perspective of the material and symbolic transformations it brings. The construction goes beyond the existence of water infrastructure, as it represents an instrument that transforms reproduction structures and, therefore, should be analyzed considering its double aspects: the aspect of water infrastructure that allows decentralized access to water and other aspects such as rights, the gender division of labor, autonomy, and women's empowerment.

However, it should be emphasized that despite the program benefits, the cistern is not a sufficient condition to guarantee access to water, as it was observed that there was not always enough water to fill the cistern. The standardized size of the water reservoir brings limitations that derive from variations in the rainfall regime of the different microregions that make up the semiarid regions and the number of members in the beneficiary families. The use of cisterns as reservoirs for storing water from sources other than rainwater (e.g., from underground dams and wells), despite the dependence on natural phenomena, leads to the perception that this social technology has a great impact on diminishing the gender division of work in women's daily life. However, filling cisterns by water-tank trucks with water collected in ways that do not comply with control or supervision can cause health problems for family members, which results in additional work for women. These limitations, however, do not invalidate the positive results brought by the Cisterns Program; instead, they reinforce the transformative power of the program and minimize the reproduction of the status quo.

\section{Notes}

${ }^{1} \mathrm{~N}=$ Sample number.

${ }^{2}$ CadÚnico is a federal government system with information about families in poverty and extreme poverty and is used for the allocation and monitoring of public policies (including Bolsa Família and Cisterns).

${ }^{3}$ Water Management for Food Production (GAPA) - before construction - addresses issues related to production processes, involving agroecological principles and the sustainable management of stored water; Simplified Water for Production System (SISMA) - after 
construction - is the assembly of a simplified watering system with water savings and exchanges among farms.

\section{References:}

Articulação do Semiárido (ASA). (1999). Declaração do Semi-árido Propostas da articulação no semi-árido brasileiro para a convivência com o semi-árido e combate à desertificação. Ministério do Meio Ambiente. Disponível

em: http://www.mma.gov.br/estruturas/sedr_desertif/_arquivos/declaracao_se miarido.doc > Acesso em 18 de set. de 2019.

Bennett, V., Davila-Poblete, S, Nieves Rico, M. (2008). "Water and gender: the unexpected connection that really matters". Journal of International Affairs, 61 (2).

Bisilliat, J.; Verschuur, C. (2000). "Le Genre: un outil nécessaire introduction à une problématique". Cahiers Genre et Développement. L’Harmattan.

Campos, A.; Alves, A. (2014) O Programa Água para Todos: ferramenta poderosa contra a pobreza. In Campello, T.; Falcão, T.; Costa, P. (Eds.), $O$ Brasil sem miséria, (pp.46-92). Ministério do Desenvolvimento Social e Combate à Fome.

Costa, B.; Dias, R. (2013). Estado e sociedade civil na implantação de políticas de cisternas. In Costa, A. B. (Ed.), Tecnologia Social e Políticas Públicas (pp. 33-64). Instituto Pólis.

Deressa, T. T. et al. (2009). "Determinants of farmers' choice of adaptation methods to climate change in the Nile Basin of Ethiopia". Global Environmental Change, v. 19, n. 2, 248-255.

Durán, M. A. (2007). El Valor del Tiempo: cuantas horas te faltan al día? Espasa Calpe.

Ericksen, P. J. et al. (2010) Adapting Food Systems. In Ingram, J.; Ericksen, P; Liverman, D. Food Security and Global Environmental Change. Earthscan. 352.

Ferreira, I.A.R. (2009). Água e política no sertão: desafios ao Programa Um Milhão de Cisternas. Dissertação de Mestrado, CDS-UNB.

Finan, T. J.; Nelson, D. R. (2001). "Making rain, making roads, making public and private adaptations to drought in Ceará, Northeast Brazil". Climate Research, v. 19, n. 2, 97-108. 
93 Nogueira, Mesquita, Cavalcante, Rodrigues, SaitoRainwater Harvesting

Fraser, N. (1992). Rethinking the Public Sphere: A contribution to the Critique of Actually Existing Democracy. In Calhoun, C. Habermas and the Public Sphere. The MIT Press, Massachussetts.

Gonçalves, H. V. B.; Rios, M. L.; Carvalho, A. (2013). Avaliação do manejo de agroecossistemas familiares atendidos pelo programa p1+ 2 na comunidade Inácio João, município de Caém, Bahia. Enciclopédia Biosfera, Centro Científico Conhecer, v. 9, n. 16, (p. 17).

Grainger-Jones, E. (2012). "Climate smart smallholder agriculture: What's different?" IFAD Occasional paper, (pp. 1-23).

Grant, M. (2017). Action in piece: Gender equality and inclusion in water resources management. Working Papers. Global Water Partnership.

Habermas, J. (1989). The Public Sphere: An Encyclopedia Article. In BRONNER, S.; KELLNER, D, Critical theory and society. Routledge, 136-142.

Hastenrath, S. (2011) "Exploring the climate problems of Brazil's Northeast: a review. Climatic Change, v. 112, n. 2, 243-251.

Hirata, H. (1998). "Reestruturação produtiva, trabalho e relações de gênero". Revista Latinoamericana de Estudios del Trabajo: Gênero, Tecnologia e Trabalho, 4, (7), 5-28.

Jackson, C. (1998). "Gender, irrigation, and environment: Arguing for agency". Agriculture and Human Values, 15, 313-324.

Kahinda, J; Taigbenu; Boroto, J. (2010). "Domestic rainwater harversting to improve water supply in rural South Africa". Physics and Chemistry of the Earth, 35, 742-751.

Kergoat, D. (2000). Division sexuelle du travail et rapports sociaux de sexe. In Hirata, H; Laborie, F.; Le Doaré, H. e Senotier, D. (Eds.), Dictionnaire Critique du Féminisme (pp. 35-44). PUF.

Kumasi, T. C.; Antwi-Agyei, P.; Obiri-Danso, K. (2017). "Small-holder farmers' climate change adaptation practices in the Upper East Region of Ghana". Environment, Development and Sustainability, v. 21, n. 2, 745762.

Lemos, M. R. C. (2007). Drought, Governance and Adaptive Capacity in North East Brazil: A Case Study of Ceará. In UNDP - Human Development Report 2007/2008 (pp. 1-16). 
Lima, S; Asa, A; Brito, T; Freita, M; Anzolini.. (2007). Avaliação de impacto social do programa de cisternas. In Vaitsman, J.; Paes-Sousa, R. (Eds.) Avaliação de políticas e programas do MDS: resultados, MDS/SAGI.

Lindoso, D. \& Al. (2018). Harvesting Water for Living with Drought: Insights from the Brazilian Human Coexistence with Semi-Aridity Approach towards Achieving the Sustainable Development Goals, Sustainability, 10, 622, doi:10.3390/su10030622.

Livingstone, I.; Assunção, M. (1989). Government policies towards drought and development in the Brazilian Sertão. Development and Change, v. 20, n. 3, 461-500.

Marengo, J. A. (2008). Vulnerabilidade, Impactos e Adaptação à Mudança do Clima no Semi-Árido do Brasil. In Parcerias Estratégicas. Mudança do Clima no Brasil: Vulnerabilidade, impactos e adaptação, CGEE.

Milhorance, C.; Sabourin, E.; Chechi, L. (2018). Adaptação às mudanças climáticas e integração de políticas públicas no semiárido pernambucano: Série Working Papers. Universidade de Brasilia.

Moraes, A.; Rocha, C. (2013). "Gendered waters: the participation of women in the 'One Million Cisterns' rainwater harvesting program in the Brazilian Semi-Arid region”. Journal of Cleaner Production, 60, 163-169.

Murillo, S. (2006). El Mito de la Vida Privada: de la entrega al tiempo proprio. Siglo XXI.

Nogueira, D. (2017). "Segurança hídrica, adaptação e gênero: o caso das cisternas para captação de água de chuva no semiárido brasileiro". Sustentabilidade em Debate, v. 8, n. 3, 22-36.

Nogueira, D. (2013). "Femmes et eau dans le Sertão. Le programme Un million de citernes", Cahiers des Amériques Latines, 63-64, http://journals.openedition.org/cal/790; DOI: 10.4000/cal.790.

Nogueira, D. (2009). Gênero e água - desenhos do Norte, alternativas do Sul: análise da experiência do semiárido Brasileiro na construção do desenvolvimento democrático. Tese de Doutorado. Universidade de Brasília.

Pantaleão F., Elvis et al. (2015). "Cisternas de produção para melhoria da qualidade de vida no Semiárido do estado de Pernambuco". Revista Verde de Agroecologia e Desenvolvimento Sustentável, v. 10, n.4. 


\section{Nogueira, Mesquita, Cavalcante, Rodrigues, Saito- Rainwater Harvesting}

Parpart, J. (2009). Fine words, failed policies: gender mainstreaming in an insecure and unequal world. In: LECKIE, J. (Ed.), Development in an Insecure and Gendered World. Ashgate Publishers.

Painel Brasileiro de Mudanças Climáticas. (PBMC). (2013). Impactos, Vulnerabilidades e Adaptação: Primeiro Relatório de Avaliação Nacional, Contribuição do Grupo de Trabalho 2.

Petersen, P.; Silveira, L. M.; Freire, A. G. (2014). "Intensificação sem simplificação: estratégia de combate à desertificação". Revista Agriculturas: experiências em agroecologia, Separata, v. 9, n. 13.

Ryan, M.P. (1992). Gender and Public Access: Women's Politics in Nineteenth-Century America. In CALHOUN, C. Habermas and the Public Sphere. The MIT Press.

Santos, K.F.S. (2017). "O programa "uma terra e duas águas-p1+2" como instrumento político-pedagógico e social na promoção da segurança alimentar e nutricional". Revista Macambira, v. 1, n. 1.

Sena A, Freitas C, Feitosa Souza P, Carneiro F, Alpino T, Pedroso M, Corvalan C, Barcellos C. (2018). "Drought in the Semiarid Region of Brazil: Exposure, Vulnerabilities and Health Impacts from the Perspectives of Local Actors". PLOS Currents Disasters. 29. Edition 1. doi: 10.1371/currents.dis.c226851ebd64290e619a4d1ed79c8639.

Silva, R. M. A. (2003). "Entre dois paradigmas: combate à seca e convivência com o semi-árido". Sociedade e Estado, v. 18, n. 1-2, 361-385.

Silva, N. L. A. et Al. (2013). "Impactos Sócioeconômicos do Projeto Cisternas em Comunidades do Município de Ibipeba, Bahia". Enciclopédia Biosfera, v. 9, n. $16,21$.

Silva, D. (2014). "Combate à desertificação e a COP dos Pobres". Terceiro Incluído. Universidade Federal de Goiás, v. 4, n. 1, 1-23.

Sivakumar, M. V. K.; Das, H. P.; Brunini, (2005). O. "Impacts of present and future climate variability and change on agriculture and forestry in the arid and semi-arid tropics". Climate Change Knowledge Network, Foundation Paper, 31-72.

Smit, B.; Skinner, M. W. (2002). "Adaptation options in agriculture to climate change: a typology". Mitigation and Adaptation Strategies for Global Change, v. 7, n. 1, 85-114.

Suárez, M.; Teixeira, M. (2012). O Programa Bolsa Família e o enfrentamento das desigualdades de gênero: o desafio de promover o reordenamento do 
espaço doméstico e o acesso das mulheres ao espaço público. Cadernos de Estudos - Desenvolvimento Social em Debate. Universidade de Brasília. United Nations Research Institute For Social Development (UNRISD). (2016). The Gender Dimensions of Drought in Fedis Woreda District, Etiopia. Working Paper.

$\mathrm{Yu}$, Q. et Al. (2012). "Proposing an interdisciplinary and cross-scale framework for global change and food security researches". Agriculture, Ecosystems and Environment, v. 156, 57-71.

Zwarteveen, M.; Bennett, V. (2005). "The Connection between Gender and Water Management” In Bennett, V.; Dávila-Poblete, S.; Nieves Rico, M. (Eds.) Opposing Currents: The Politics of Water and Gender in Latin America, (pp.13-29). University of Pittsburgh Press. 
97 Nogueira, Mesquita, Cavalcante, Rodrigues, SaitoRainwater Harvesting

Daniela Nogueira. University of Brasilia, Center for Sustainable Development. (Brasilia)

ORCID: 0000-0002-2474-8916

Patricia Mesquita. University of Brasilia, Center for Sustainable Development. (Brasilia)

ORCID: 0000-0002-3755-0212

Louise Cavalcante. Wageningen University and Research, Public Administration and Policy Group. (Brasilia)

ORCID: 0000-0002-8773-540X

Saulo Rodrigues Filho. University of Brasilia, Center for Sustainable Development. (Brasilia)

ORCID: 0000-0001-5937-8874

Carlos Saito. University of Brasilia, Department of Ecology, Institute of Biological Sciences. (Brasilia)

ORCID: 0000-0002-5757-9629

Contact Address: danielanogueiracds@gmail.com 